\title{
Karakteristik Fisik Kue Kembang Goyang dengan Substitusi Jewawut (Setaria italica L. P. Beauv.) dan Variasi Konsentrasi Santan
}

\author{
Physical Characteristics of Kue Kembang Goyang with Foxtail Millet (Setaria italica L. P. \\ Beauv.) Substitution and Variation of Coconut Milk Concentration
}

\section{Nuri A. Anugrahati*, Jane Naomi}

\begin{abstract}
Program Studi Teknologi Pangan, Fakultas Sains dan Teknologi, Universitas Pelita Harapan, Jl. M.H. Thamrin Boulevard 1100, Lippo Karawaci, Tangerang Banten 15811 Indonesia
\end{abstract}

*Penulis korespondensi: Nuri A. Anugrahati, e-mail: nuri.anugrahati@uph.edu

Tanggal submisi: 17 September 2020; Tanggal penerimaan: 12 Februari 2021

\begin{abstract}
"Kue kembang goyang" is a popular Indonesian traditional food made from rice flour. Millet flour with an amylose content equal to rice flour can be substituted for rice flour in the "kue kembang goyang" formulation. The research aimed to determine the amylose content of 3 varieties of foxtail millet flour (Setaria italica (L.) P. Beauv.) and to determine the best formula of "kue kembang goyang" in several ratios of foxtail millet flour:rice flour-based on crunchiness and oil absorption. The research was divided into two phases. Phase I, involved determining the amylose content of the three varieties of foxtail millet flour (erecta, compacta, glabra) and stage II involved determining the physical characteristics of "kue kembang goyang" in the ratio of foxtail millet flour:rice flour (0: 100, 20:80, 40:60, 60:40, 80:20) and concentration of coconut milk (20\%, 30\%, 40\%). The result of phase I showed that the highest amylose content was found in foxtail millet flour of erecta variety $(37.91 \pm 0.51 \%)$. The phase II result showed that the ratio of foxtail millet flour:rice flour affected the texture and absorption of oil of "kue kembang goyang". The higher the ratio of foxtail millet flour, the lower the count peaks, toughness, oil absorption, but the higher fracturability of "kue kembang goyang". Increasing the concentration of coconut milk can increase count peaks, toughness, fracturability, and an oil absorption of "kue kembang goyang". The best formula of "kue kembang goyang" was obtained in the ratio of foxtail millet flour:rice flour 60:40 and 30\% of coconut milk-based on the highest crunchiness and oil absorption resembled the control.
\end{abstract}

Keywords: Coconut milk; foxtail millet; "kue kembang goyang”; physical characteristics

(C) The Authors. Publisher Universitas Pattimura. Open access under CC-BY-SA license.

\begin{abstract}
ABSTRAK
Kue kembang goyang merupakan kue tradisional Indonesia yang popular dan terbuat dari tepung beras. Tepung beras dalam formula kue kembang goyang dapat diganti tepung jewawut yang memiliki kadar amilosa menyamai tepung beras. Tujuan penelitian adalah menentukan kadar amilosa tiga varietas tepung jewawut (Setaria italica (L.) P. Beauv.) dan menentukan formula terbaik kue kembang goyang pada beberapa rasio tepung jewawut:tepung beras berdasarkan kerenyahan dan absorpsi minyak. Penelitian dibagi menjadi tahap I yaitu menentukan kadar amilosa ke-3 varietas jewawut (erecta, compacta, glabra) dan tahap II yaitu menentukan karakteristik fisik kue kembang goyang pada rasio tepung jewawut:tepung beras $(0: 100,20: 80,40: 60,60: 40,80: 20)$ dan konsentrasi santan $(20,30,40 \%)$. Hasil penelitian tahap I menunjukkan kadar amilosa tertinggi pada tepung jewawut varietas erecta $(37,91 \pm 0,51 \%)$. Hasil penelitian tahap II menunjukkan rasio tepung jewawut:tepung beras berpengaruh terhadap tekstur dan absorpsi minyak kue kembang goyang. Semakin tinggi rasio tepung jewawut dapat menurunkan count peaks, toughness, absorpsi minyak, namun meningkatkan daya patah kue kembang goyang. Peningkatan konsentrasi santan dapat meningkatkan count peaks, toughness, daya patah, dan absorpsi minyak kue kembang goyang. Formula terbaik kue kembang goyang diperoleh pada rasio tepung jewawut:tepung beras 60:40 dan konsentrasi santan 30\% berdasarkan kerenyahan tertinggi dan absorpsi minyak yang menyerupai kontrol.
\end{abstract}

Kata kunci: Karakteristik fisik; kue kembang goyang; jewawut; santan

(C) Penulis. Penerbit Universitas Pattimura. Akses terbuka dengan lisensi CC-BY-SA. 


\section{PENDAHULUAN}

Kue kembang goyang merupakan kue kering tradisional khas Betawi yang berbentuk lingkaran seperti bunga yang dimasak dengan cara digoreng. Pemberian nama kembang goyang berasal dari alat dan teknik menggorengnya. Adonan kue kembang goyang berupa adonan kental yang dicetak menggunakan alat berbentuk kembang dan selanjutnya digoyang-goyang untuk melepaskan kue yang sudah matang pada saat menggoreng. Kue kembang goyang memiliki tekstur yang renyah, rasa manis, dan warna kuning kecokelatan. Bahan-bahan dalam pembuatan kue kembang goyang meliputi tepung beras, tepung tapioka, telur, gula, garam, santan, dan air (Fuadah dan Afifah, 2016). Penggunaan beras yang telah dikenal sebagai makanan pokok masyarakat Indonesia dan pemanfaatannya ke dalam berbagai formula produk makanan tradisional di Indonesia mendorong usaha mencari alternatif tepung lokal untuk mensubstitusi tepung beras. Salah satu tepung lokal yang dapat digunakan untuk mensubstitusi tepung beras adalah tepung jewawut.

Jewawut (Setaria italica (L.) P. Beauv.) merupakan tanaman yang dapat tumbuh pada tanah yang kurang subur dan musim kemarau, serta masa panennya relatif singkat. Jewawut memiliki kadar amilosa yang menyerupai beras, yaitu $28,60 \%$ sehingga dapat digunakan untuk mensubstitusi tepung beras dalam produk pangan (Annor et al., 2014). Tepung beras memiliki kadar amilosa sebesar 20-29\% (Luna et al., 2015). Sebagian besar masyarakat belum mengenal jewawut sebagai sumber pangan dan hanya dijadikan sebagai pakan burung sehingga masih terbatas pemanfaatannya. Jewawut mengandung 60-70\% karbohidrat; 7-11\% protein; 1,5-5\% lemak; 2-7\% serat kasar; 298,65$342,74 \mathrm{mg} / 100 \mathrm{~g}$ vitamin $\mathrm{E} ; 15,34-18,60 \mathrm{mg} / 100 \mathrm{~g}$ vitamin B6; 20,72-21,54 ppm Fe; 14,24-15,68 ppm Ca (Juhaeti et al., 2019; Sarita dan Singh, 2016).

Kerenyahan merupakan karakteristik utama kue kembang goyang. Kerenyahan kue kembang goyang dapat dipengaruhi oleh kadar amilosa. Kadar amilosa tepung jewawut menyamai tepung beras sehingga tepung jewawut dapat digunakan untuk mensubstitusi tepung beras dalam formulasi kue kembang goyang. Namun karakteristik kerenyahan kue kembang goyang yang berhubungan dengan kadar amilosa masih sedikit dilaporkan. Penelitian sebelumnya masih terbatas pada pemanfaatan bekatul untuk mensubstitusi tepung beras dan tapioka dalam formula kue kembang goyang. Tepung bekatul $60 \%$ dapat mensubstitusi tepung beras dan tapioka dan menghasilkan karakteristik kue kembang goyang yang renyah dan cukup disukai panelis (Fuadah dan Afifah, 2016). Penelitian lain melaporkan kadar amilosa tepung berhubungan dengan absorpsi minyak pada produk gorengan. Kadar amilosa berpengaruh terhadap absorpsi minyak pada produk yang digoreng karena terjadi interaksi amilosa dengan lipida selama penggorengan. Interaksi antara amilosa dengan lipida terjadi akibat struktur heliks amilosa yang bersifat hidrofobik dan mampu memerangkap lipida (Chen et al., 2019).

Selain kadar amilosa, kerenyahan kue kembang goyang dapat dipengaruhi oleh konsentrasi santan. Santan dilaporkan dapat meningkatkan kerenyahan pada produk kue kering sejenis lainnya yaitu kue semprong. Peningkatan kerenyahan dipengaruhi oleh kandungan lemak yang tinggi dalam santan, yaitu $88,30 \%$. Semakin tinggi kadar lemak dapat menurunkan daya patah dan meningkatkan kerenyahan pada produk kue semprong. Kue semprong yang memiliki kadar lemak 7,32\% memiliki daya patah $0,69 \mathrm{~kg} / \mathrm{cm}^{2}$, sedangkan kue semprong dengan kadar lemak 4,11\% memiliki daya patah $0,83 \mathrm{~kg} / \mathrm{cm}^{2}$ (Harijono et al., 2012). Belum dilaporkan pengaruh varietas tepung jewawut, rasio tepung jewawut dan tepung beras, serta konsentrasi santan terhadap karakteristik fisik kue kembang goyang, khususnya pada parameter tekstur dan absorpsi minyak. Oleh karena itu penelitian ini bertujuan untuk menentukan kadar amilosa tepung jewawut (Setaria italica (L.) P. Beauv.) varietas erecta, compacta, glabra dan menentukan formula terbaik kue kembang goyang pada beberapa rasio tepung jewawut dan tepung beras berdasarkan kerenyahan dan absorpsi minyak.

\section{METODE PENELITIAN}

\section{Bahan}

Bahan yang digunakan pada penelitian adalah jewawut varietas erecta, compacta, dan glabra dari Polewali Mandar (Sulawesi Barat). Kue kembang goyang komersial dibeli secara online melalui Tokopedia (Indonesia).

\section{Prosedur Penelitian}

\section{Penelitian Tahap I}

Pembuatan tepung jewawut mengacu pada metode Himabindu dan Devanna (2017) dengan modifikasi. Biji jewawut varietas erecta, compacta, dan glabra masing-masing dibersihkan dari kotoran, kemudian dicuci di bawah air mengalir hingga 

Terakreditasi RISTEKDIKTI Peringkat SINTA 3, SK. 200/M/KPT/2020

air cucian menjadi jernih. Selanjutnya biji jewawut yang bersih ditiriskan terlebih dahulu kemudian dikeringkan menggunakan pengering cabinet pada suhu $60^{\circ} \mathrm{C}$ selama 20 jam sehingga diperoleh biji jewawut kering. Biji jewawut kering dijadikan tepung dengan menggunakan dry crusher (Sharp, Indonesia). Tepung jewawut yang diperoleh selanjutnya diayak mengunakan ayakan berukuran 80 mesh. Selanjutnya tepung jewawut lolos ayakan 80 mesh digunakan sebagai bahan untuk membuat kue kembang goyang pada penelitian tahap II.

\section{Penelitian Tahap II}

Pembuatan kue kembang goyang mengacu pada metode Andayani (2013) dengan modifikasi. Tepung jewawut dicampur dengan tepung beras (Rose Brand, Indonesia) (0:100, 20:80, 40:60, 60:40, 80:20), gula pasir (Gulaku, Indonesia) 8\%; garam (Dolphin, Indonesia) 0,26\%; vanili (Koepoekoepoe, Indonesia) $0,26 \%$; dicampur dalam wadah. Kemudian telur (campuran putih dan kuning telur) $17,33 \%$ dimasukkan perlahan-lahan sambil diaduk. Selanjutnya santan kental (Kara, Indonesia) (20\%, $30 \%, 40 \%)$ dicampurkan dengan air $(20,8 \% ; 10,3 \%$; $0,8 \%$ ) hingga homogen. Larutan santan dimasukkan sedikit demi sedikit ke dalam adonan hingga larut dan adonan menjadi homogen kembali. Sementara itu minyak (Sania Royale, Indonesia) dipanaskan dalam wajan hingga mencapai suhu $160^{\circ} \mathrm{C}$. Cetakan kue kembang goyang dipanaskan dalam minyak terlebih dahulu kemudian dicelupkan pada adonan tanpa menutupi bagian atas cetakan. Adonan yang sudah melekat pada cetakan dicelupkan ke dalam minyak panas sambil digoyang hingga terlepas dari cetakan. Penggorengan dilakukan selama 30 detik hingga kue kembang goyang berwarna kuning kecokelatan. Setelah matang kue ditiriskan.

\section{Analisis Kadar Amilosa Tepung Jewawut (Andarwulan et al., 2011)}

Kurva standar amilosa dibuat dengan memasukkan $40 \mathrm{mg}$ amilosa murni (Merck, Jerman) ke dalam labu takar $100 \mathrm{~mL}$. Satu $\mathrm{mL} \mathrm{95 \%} \mathrm{etanol}$ (Merck, Jerman) dan $9 \mathrm{~mL}$ larutan $1 \mathrm{~N} \mathrm{NaOH}$ (Merck, Jerman) ditambahkan ke dalam labu takar. Labu takar dipanaskan dalam penangas air (Memmert, Jerman) pada suhu $95^{\circ} \mathrm{C}$ selama 10 menit. Larutan kemudian didinginkan pada suhu ruang. Air destilasi ditambahkan pada labu takar sampai tanda batas. Larutan tersebut disebut sebagai larutan stok. Larutan stok tersebut diambil sebanyak $1,2,3,4$, dan $5 \mathrm{~mL}$ dengan menggunakan pipet, kemudian masing-masing dipindahkan masing- masing ke dalam labu takar $100 \mathrm{~mL}$. Sebanyak 0,2; 0,4; 0,6; 0,8; dan $1 \mathrm{~mL}$ larutan $\mathrm{CH}_{3} \mathrm{COOH}$ (Merck, Jerman) $1 \mathrm{~N}$ ditambahkan ke dalam masing-masing labu takar tersebut. Larutan iodin (Merck, Jerman) sebanyak $2 \mathrm{~mL}$ ditambahkan ke dalam setiap labu takar, kemudian ditambahkan air destilasi hingga tanda batas. Larutan didiamkan terlebih dahulu selama 20 menit, lalu diukur absorbansinya menggunakan spektrofotometer UV-vis U-1800 (Hitachi, Jepang) pada panjang gelombang $625 \mathrm{~nm}$. Analisis kadar amilosa pada sampel dilakukan dengan 100 mg sampel dimasukkan ke dalam labu takar $100 \mathrm{~mL}$ dan ditambahkan $1 \mathrm{~mL} 95 \%$ etanol dan $9 \mathrm{~mL} 1 \mathrm{~N}$ $\mathrm{NaOH}$. Larutan kemudian dipanaskan dengan penangas air pada suhu $95^{\circ} \mathrm{C}$ selama 10 menit. Larutan didinginkan hingga suhu ruang, kemudian larutan ditambah dengan air destilasi sampai tanda batas dan dihomogenkan. Sebanyak $5 \mathrm{~mL}$ larutan diambil dengan pipet, kemudian dipin-dahkan ke dalam labu takar $100 \mathrm{~mL}$. Sebanyak $1 \mathrm{~mL}$ larutan $\mathrm{CH}_{3} \mathrm{COOH} 1 \mathrm{~N}$ dan $2 \mathrm{~mL}$ larutan iodin ditambahkan ke dalam labu takar tersebut, kemudian ditambahkan air destilasi sampai tanda batas. Larutan didiamkan selama 20 menit, kemudian diukur absorbansinya menggunakan spektrofotometer UVvis U-1800 pada panjang $625 \mathrm{~nm}$. Kadar amilosa ditentukan berdasarkan persamaan kurva standar yang diperoleh dan dihitung dengan rumus:

$$
\text { Kadar amilosa }(\%)=\frac{C \times V \times f p}{W} \times 100 \%
$$

Keterangan: $\mathrm{C}=$ konsentrasi amilosa (ppm); $\mathrm{V}=$ volume akhir larutan $(\mathrm{L}) ; \mathrm{fp}=$ faktor pengenceran; $\mathrm{W}=$ berat tepung awal (mg)

\section{Analisis Kadar Pati Resisten Tepung Jewawut (AOAC, 2012)}

Sampel sebanyak 0,5 g dimasukkan ke dalam gelas Erlenmeyer dan ditambah $25 \mathrm{~mL}$ larutan buffer fosfat (Merck, Jerman) 0,1 M pH 7. Campuran diaduk sampai terbentuk suspensi, selanjutnya ditambahkan $0,1 \mathrm{~mL}$ enzim $\alpha$-amilase (Sigma-Aldrich, USA) ke dalam Erlenmeyer. Erlenmeyer lalu ditutup dengan aluminium foil dan diinkubasi dalam penangas air pada suhu $100^{\circ} \mathrm{C}$ selama 15 menit sambil diaduk sesekali. Sampel diangkat dan didinginkan lalu ditambahkan $20 \mathrm{~mL}$ air destilasi dan ditambahkan $5 \mathrm{~mL} \mathrm{HCl}$ (Merck, Jerman) $1 \mathrm{~N}$. Selanjutnya enzim pepsin (SigmaAldrich, USA) $1 \%$ sebanyak $1 \mathrm{~mL}$ ditambahkan ke dalam Erlenmeyer berisi sampel, ditutup, dan diinkubasi kembali dalam penangas air selama 30 menit. Kemudian ditambahkan $20 \mathrm{~mL}$ air destilasi, $5 \mathrm{~mL} \mathrm{NaOH} 1 \mathrm{~N}$, dan enzim $\beta$-amilase (SigmaAldrich, USA) sebanyak $0,1 \mathrm{~mL}$ ke dalam 
Erlenmeyer. Erlenmeyer ditutup dan diinkubasi dalam penangas air bergoyang selama 30 menit. kemudian disaring menggunakan kertas saring. Residu yang diperoleh selanjutnya dilarutkan dan dianalisis kadar patinya. Residu dipindahkan secara kuantitatif dari kertas saring ke dalam Erlenmeyer dengan cara mencuci dengan $200 \mathrm{~mL}$ air dan ditambahkan $20 \mathrm{~mL} \mathrm{HCl} \mathrm{25 \% .} \mathrm{Erlenmeyer} \mathrm{ditutup}$ dengan pendingin balik dan dipanaskan di atas penangas air sampai mendidih selama 2,5 jam. Sampel dibiarkan dingin dan dinetralkan dengan larutan $\mathrm{NaOH} 1 \mathrm{~N}$ dan diencerkan sampai volume $250 \mathrm{~mL}$. Campuran yang diperoleh kemudian disaring kembali menggunakan kertas saring. Kadar gula yang dihitung dinyatakan sebagai glukosa dari filtrat yang diperoleh. Filtrat jernih sebanyak $1 \mathrm{~mL}$ selanjutnya diambil dan ditambahkan $1 \mathrm{~mL}$ reagen Nelson C (Nelson A 25:1 Nelson B) (SigmaAldrich, USA). Filtrat dipanaskan dalam penangas air pada suhu $100^{\circ} \mathrm{C}$ selama 30 menit dan didinginkan. Kemudian ditambahkan $1 \mathrm{~mL}$ Arseno Molibdat (Sigma-Aldrich, USA) dan dicampur hingga homogen. Selanjutnya akuades ditambahkan sampai volume menjadi $10 \mathrm{~mL}$. Larutan yang telah diencerkan kemudian diukur absorbansinya menggunakan spektrofotometer UV-vis U-1800 pada panjang gelombang $540 \mathrm{~nm}$. Data yang diperoleh kemudian dihitung menggunakan kurva standar. Kadar pati resisten dihitung dengan rumus:

Kadar pati resisten $(\%)=\frac{1-\mathrm{G} \times 0,9}{\text { Berat sampel }} \times 100 \%$ Keterangan: $\mathrm{G}=$ Berat glukosa

\section{Pengujian Tekstur Kue Kembang Goyang (Paula dan Conti-Silva, 2014)}

Pengujian tekstur dilakukan menggunakan texture analyzer Barnstead dengan Ottawa cell with 8 blades (Stable Micro System TA.XT Plus, England) pada kecepatan $2 \mathrm{~mm} /$ detik dan jarak 75 mm. Parameter tekstur kue kembang goyang yang diukur meliputi toughness, kerenyahan (count peaks), dan daya patah (fracturability).

\section{Pengujian Absorpsi Minyak Kue Kembang Goyang (Mousa, 2016)}

Absorpsi minyak merupakan selisih kadar lemak sebelum dan setelah proses penggorengan dibandingkan dengan berat kering adonan yang digunakan. Kadar lemak dianalisis sesuai prosedur AOAC (2012). Absorpsi minyak kue kembang goyang dihitung dengan rumus:

Absorpsi minyak $(\%)=\frac{\left(\mathrm{KL}_{2} \times \mathrm{W}_{2}\right)-\left(\mathrm{KL}_{1} \times \mathrm{W}_{1}\right)}{\mathrm{W}_{0}} \times 100 \%$
Keterangan: $\mathrm{KL}_{1}=$ Kadar lemak sebelum penggorengan (\%); $\mathrm{KL}_{2}=$ Kadar lemak setelah penggorengan $(\%) ; \mathrm{W}_{1}=$ Berat adonan sebelum penggorengan $(\mathrm{g}) ; \mathrm{W}_{2}=$ Berat produk setelah penggorengan $(\mathrm{g}) ; \mathrm{W}_{0}=$ Berat kering adonan $(\mathrm{g})$.

\section{Pengujian Penguapan Air (Mousa, 2016)}

Penguapan air merupakan selisih kadar air sebelum dan setelah proses penggorengan dibandingkan dengan kadar air awal. Kadar air dianalisis sesuai prosedur AOAC (2012). Penguapan air kue kembang goyang dihitung dengan rumus:

$$
\text { Penguapan air }(\%)=\left(\frac{\mathrm{KA}_{1}-\mathrm{KA}_{2}}{\mathrm{KA}_{1}}\right) \times 100 \%
$$

Keterangan: $\mathrm{KA}_{1}=$ Kadar air sebelum penggorengan; $\mathrm{KA}_{2}=\mathrm{Kadar}$ air setelah penggorengan

\section{Rancangan Percobaan}

Rancangan percobaan penelitian tahap I dan II adalah rancangan acak lengkap. Perlakuan pada tahap I adalah 3 varietas jewawut (erecta, compacta, glabra) sedangkan perlakuan pada tahap II adalah rasio tepung jewawut:tepung beras $(0: 100$, 20:80, 40:60, 60:40, dan 80:20) dan konsentrasi santan $(20,30$, dan 40\%). Data dianalisis secara statistik dengan univariate menggunakan SPSS versi 23. Uji lanjut Duncan Multiple Range Test dilakukan untuk menentukan perbedaan antar perlakuan dengan tingkat kepercayaan 95\% ( $\alpha=0,05)$.

\section{HASIL DAN PEMBAHASAN}

\section{Pemilihan Tepung Jewawut Berdasarkan Kadar Amilosa}

Berdasarkan hasil analisis statistik, kadar amilosa ketiga varietas tepung jewawut berbeda signifikan $(p<0,05)$. Hasil analisis kadar amilosa tepung jewawut varietas erecta, compacta dan glabra dapat dilihat pada Tabel 1. Kadar amilosa tertinggi terdapat pada tepung jewawut varietas erecta dengan $37,91 \pm 0,51 \%$, diikuti oleh varietas compacta dengan kadar amilosa 24,41 $\pm 0,78 \%$ dan varietas glabra dengan kadar amilosa 21,68 \pm $0,78 \%$ walaupun kadar amilosa antara varietas compacta dan glabra tidak berbeda signifikan. Hasil ini didukung oleh penelitian sebelumnya yang menyatakan perbedaan kadar amilosa pada setiap jenis jewawut dapat dipengaruhi oleh asal geografis dan kondisi pertumbuhan (Gao et al., 2014).

Tepung jewawut yang digunakan untuk substitusi tepung beras dalam pembuatan kue 
kembang goyang adalah tepung jewawut yang memiliki kadar amilosa tertinggi, yaitu varietas erecta. Kadar amilosa yang tinggi diduga dapat meningkatkan kerenyahan dan menurunkan absorpsi minyak produk pangan. Hal ini juga didasari oleh tujuan dari penelitian, yaitu untuk menentukan karakteristik fisik kue kembang goyang yang baik berdasarkan kerenyahannya. Oleh karena itu, tepung jewawut varietas erecta dipilih sebagai bahan untuk membuat kue kembang goyang pada tahap II.

\section{Kadar Pati Resisten}

Pada tahap penelitian I dianalisis kadar pati resisten pada tepung jewawut yang memiliki kadar amilosa tertinggi. Pada Tabel 1 terlihat tepung jewawut varietas erecta memiliki kadar pati resisten sebesar 0,83 $\pm 0,03 \%$. Kadar pati resisten yang terdapat pada tepung beras dan tepung jewawut dapat digolongkan ke dalam pati resisten tipe 2. Pati resisten tipe 2 merupakan tipe pati resisten yang ditentukan oleh karakteristik alami granula patinya. Granula pati yang secara alami terdapat dalam bahan pangan dan tidak dapat dihidrolisis oleh enzim amilase pada sistem pencernaan. Granula pati tersebut tidak rentan terhadap hidrolisis enzim amilase karena sifat kristalin dan strukturnya yang kompak (Raigond et al., 2014). Oleh karena itu, dapat dinyatakan pemanfaatan tepung jewawut sebagai pensubstitusi tepung beras dalam pembu- atan kue kembang goyang dapat meningkatkan sifat fungsional dari kue kembang goyang, khususnya dari segi kadar pati resistennya.

\section{Tekstur Kue Kembang Goyang}

Tekstur yang menentukan kualitas kue kembang goyang meliputi toughness, kerenyahan (count peaks), dan daya patah (fracturability). Rasio tepung jewawut dan tepung beras, serta konsentrasi santan memberikan pengaruh yang signifikan $(p<$ 0,05) pada kue kembang goyang. Toughness kue kembang goyang dapat dilihat pada Gambar 1 . Semakin tinggi rasio substitusi tepung jewawut sampai rasio 60:40 dapat menurunkan toughness sampai 12,27 kgs karena kemampuan serat pada tepung jewawut untuk mengikat lemak pada santan sehingga menurunkan toughness. Beberapa jenis serat yang dilaporkan terdapat dalam jewawut seperti selulosa, hemiselulosa, dan pektin (Rathore et al., 2016). Semakin tinggi konsentrasi santan yang ditambahkan, maka semakin tinggi toughness kue kembang goyang. Hal ini disebabkan konsentrasi santan yang tinggi dapat meningkatkan viskositas adonan dan meningkatkan ketebalan kue kembang goyang. Semakin tebal kue kembang goyang, maka tekstur kue kembang goyang menjadi lebih keras akibat absorpsi minyak yang tidak merata dan meningkatnya toughness pada daerah permukaannya.

Tabel 1. Kadar amilosa dan pati resisten tepung jewawut berdasarkan perbedaan varietas

\begin{tabular}{ccc}
\hline Varietas & Kadar amilosa $(\%)$ & Kadar pati resisten $(\%)$ \\
\hline Erecta & $37,91 \pm 0,51^{\mathrm{b}}$ & $0,83 \pm 0,03$ \\
Compacta & $24,41 \pm 0,78^{\mathrm{a}}$ & - \\
Glabra & $21,68 \pm 0,78^{\mathrm{a}}$ & -
\end{tabular}

Keterangan: perbedaan notasi huruf menunjukkan perbedaan yang signifikan $(p<0,05)$; - (tidak dianalisis)

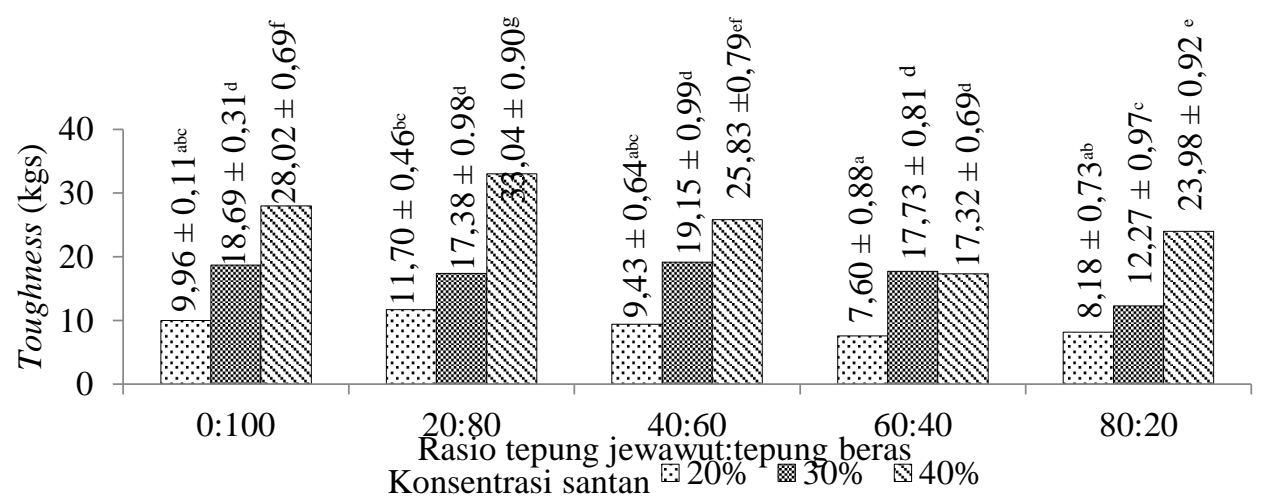

Keterangan: Perbedaan notasi huruf menunjukkan perbedaan yang signifikan $(p<0,05)$

Gambar 1. Toughness kue kembang goyang pada rasio tepung jewawut dan tepung beras serta konsentrasi santan yang berbeda 


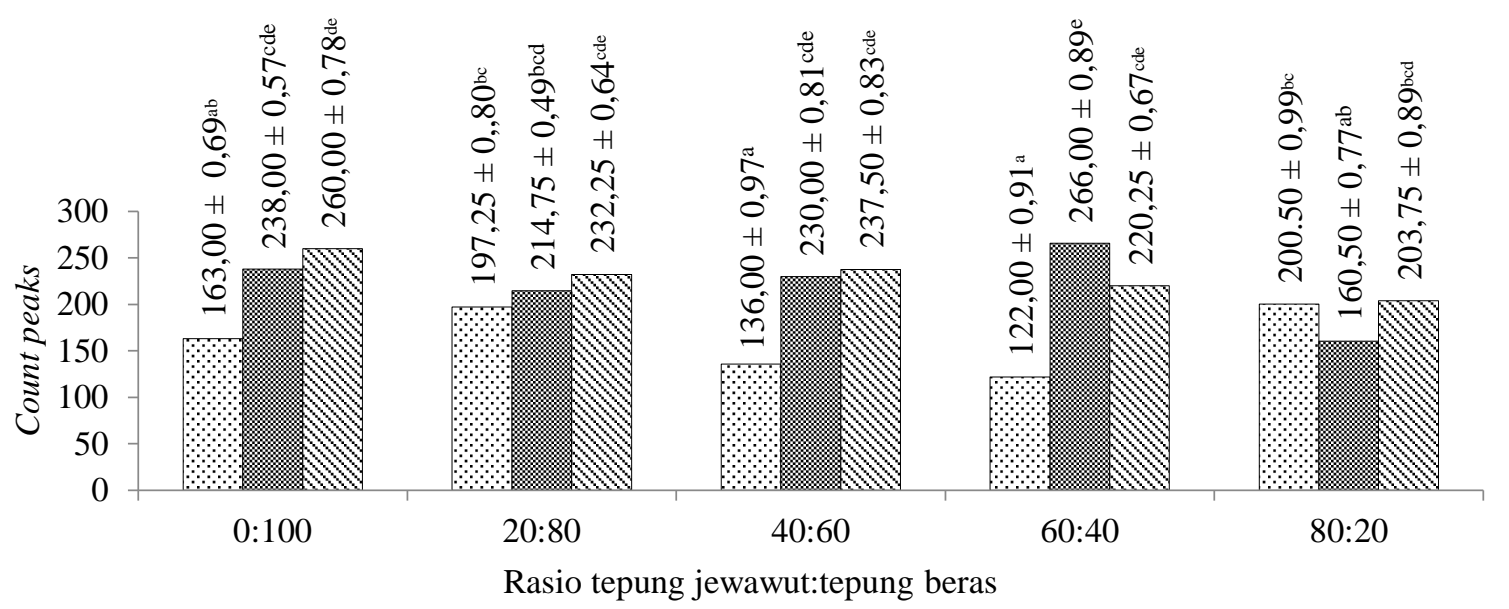

Konsentrasi santan $20 \%$ 중 $30 \%$

Keterangan: Perbedaan notasi huruf menunjukkan perbedaan yang signifikan $(p<0,05)$

Gambar 2. Count peaks kue kembang goyang pada rasio tepung jewawut dan tepung beras serta konsentrasi santan yang berbeda

Gambar 2 menunjukkan perbedaan kerenyahan (count peaks) yang signifikan $(p<0,05)$ pada kue kembang goyang dengan rasio tepung jewawut dan tepung beras serta konsentrasi santan yang berbeda. Semakin tinggi substitusi tepung jewawut dapat menurunkan kerenyahan pada konsentrasi santan 40\%. Hal ini disebabkan tingginya serat dan protein pada tepung jewawut dibandingkan dengan tepung beras. Tingginya serat dan protein dapat meningkatkan kekerasan dan menurunkan kerenyahan produk pangan. Pada konsentrasi santan $30 \%$ terjadi peningkatan kerenyahan pada rasio tepung jewawut:tepung beras 20:80, 40:60, 60:40 dibandingkan dengan kontrol. Serat yang terdapat dalam tepung jewawut mampu berikatan dengan lemak santan dan berdampak ke peningkatan kerenyahan kue kembang goyang. Hal ini sesuai dengan penelitian sebelumnya yang melaporkan struktur berpori serat mampu mengikat lemak sehingga meningkatkan kerenyahan produk deep fat fried poori (Yadav dan Rajan, 2011).

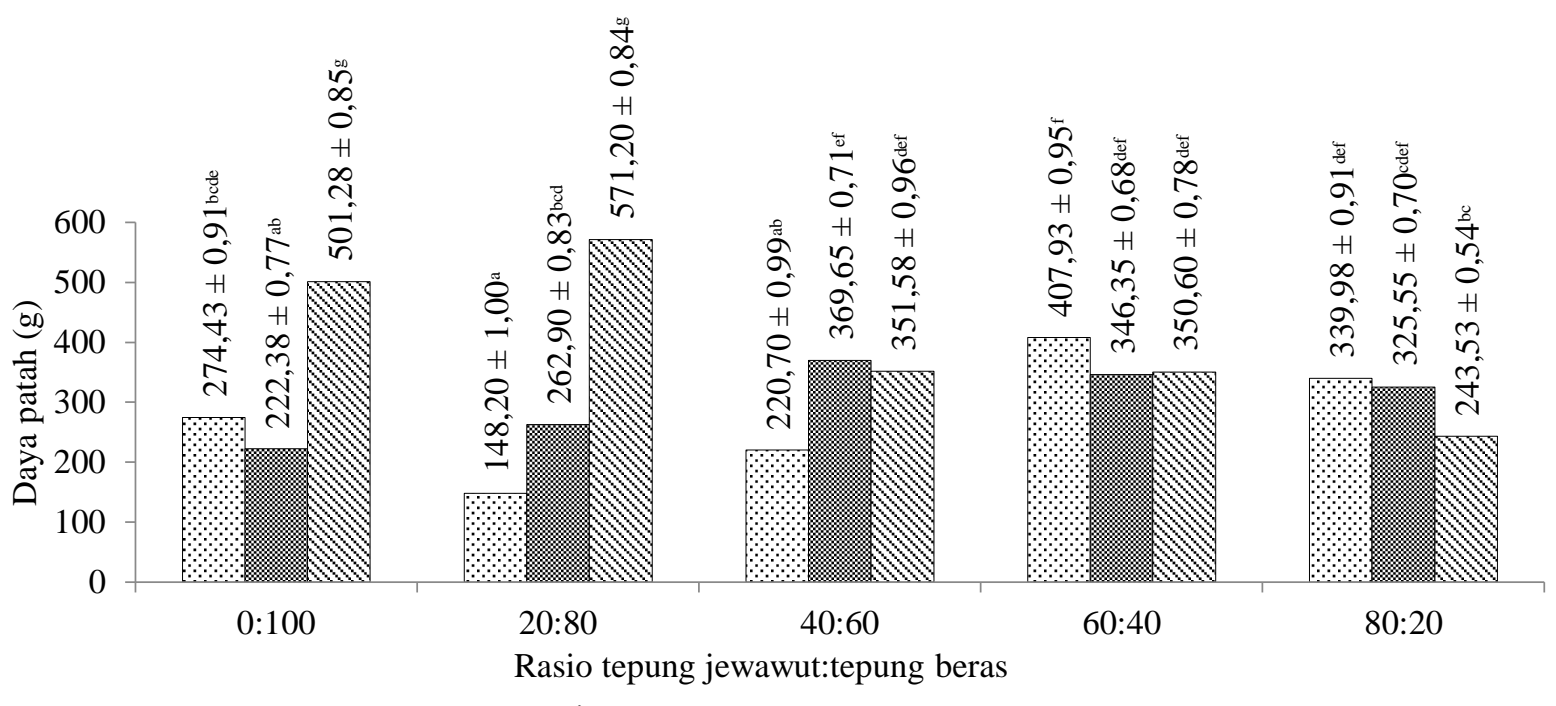

Konsentrasi santan $\quad: 20 \% \quad$ 圆 $30 \% \quad$ \$ $40 \%$

Keterangan: Perbedaan notasi huruf menunjukkan perbedaan yang signifikan $(p<0,05)$

Gambar 3. Daya patah kue kembang goyang pada rasio tepung jewawut dan tepung beras serta konsentrasi santan yang berbeda 
Daya patah kue kembang goyang dengan rasio tepung jewawut dan tepung beras serta konsentrasi santan yang berbeda memiliki perbedaan yang signifikan $(p<0,05)$. Daya patah kue kembang goyang dapat dilihat pada Gambar 3. Semakin tinggi rasio tepung jewawut khususnya pada konsentrasi santan 30\% dapat meningkatkan daya patah kue kembang goyang sampai 325,55 \pm 0,70 g. Hal ini dapat dipengaruhi oleh kandungan serat dan protein yang lebih tinggi pada tepung jewawut dibandingkan pada tepung beras. Tepung beras hanya mengandung $0,3 \%$ serat kasar (Fernando, 2013). Serat juga dilaporkan memiliki struktur yang kompleks dan membentuk ikatan yang kuat dengan air sehingga dibutuhkan gaya yang lebih besar untuk mematahkan kue kembang goyang (Harijono et al., 2012). Peningkatan konsentrasi santan dalam formulasi kue kembang goyang dapat menurunkan daya patah. Hal ini sesuai dengan penelitian sebelumnya yang melaporkan peningkatan kadar lemak dapat menurunkan daya patah dan meningkatkan kerenyahan produk kue kering (Harijono et al., 2012).

\section{Absorpsi Minyak}

Rasio tepung berpengaruh signifikan ( $p<$ $0,05)$ terhadap absorpsi minyak kue kembang goyang seperti terlihat pada Gambar 4. Selama proses penggorengan, minyak tidak hanya berperan sebagai media penghantar panas, namun ikut terserap ke dalam produk pangan. Kadar lemak kue kembang goyang sebelum proses penggorengan berkisar antara 13,25-22,95\%. Kadar lemak kue kembang goyang setelah proses penggorengan berkisar antara 36,72-58,75\%. Selama proses penggorengan, kue kembang goyang menyerap minyak sebanyak $28,81-43,85 \%$. Peningkatan rasio tepung jewawut berbanding terbalik dengan absorpsi minyak kue kembang goyang. Hal ini disebabkan tepung jewawut memiliki kadar amilosa yang lebih tinggi sehingga memiliki kemampuan absorpsi minyak goreng yang lebih rendah dibandingkan dengan tepung beras. Hal ini didukung oleh Chen et al. (2019) yang melaporkan kadar amilosa berbanding terbalik dengan absorpsi minyak pada kadar air tertentu.

Konsentrasi santan berpengaruh signifikan ( $p$ $<0,05)$ terhadap absorpsi minyak kue kembang goyang. Pengaruh konsentrasi santan yang berbeda pada absorpsi minyak kue kembang goyang dapat dilihat pada Gambar 5. Peningkatan konsentrasi santan berbanding lurus dengan absorpsi minyak kue kembang goyang. Absorpsi minyak kue kembang goyang dengan konsentrasi santan $40 \%$ $(43,34 \pm 0,89 \%)$ berbeda nyata dengan absorpsi minyak kue kembang goyang dengan konsentrasi santan 20\% (32,91 $\pm 0,25 \%)$ dan konsentrasi santan $30 \%(32,21 \pm 0,59 \%)$. Konsentrasi santan yang tinggi menyebabkan viskositas adonan meningkat sehingga meningkatkan ketebalan produk kue kembang goyang. Menurut Paz-Gamboa et al. (2015), ketebalan produk berbanding lurus dengan absorpsi minyak. Semakin tebal produk, maka absorpsi minyak semakin tinggi karena memerlukan waktu penggorengan yang lebih lama untuk mencapai tingkat kematangan yang sama dengan produk lebih tipis.

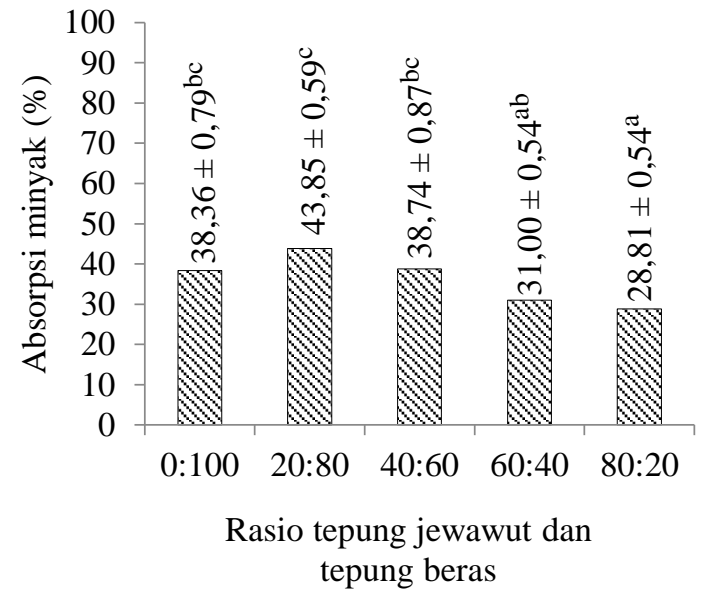

Keterangan: Perbedaan notasi huruf menunjukkan perbedaan yang signifikan $(p<0,05)$

Gambar 4. Absorpsi minyak kue kembang goyang pada rasio tepung jewawut dan tepung beras yang berbeda

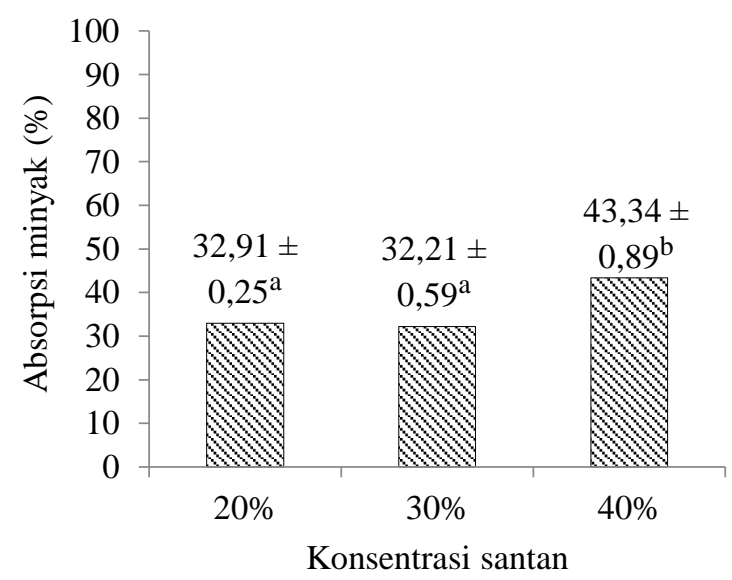

Keterangan: perbedaan notasi huruf menunjukkan perbedaan yang signifikan $(p<0,05)$

Gambar 5. Absorpsi minyak kue kembang goyang pada konsentrasi santan yang berbeda 


\section{Penguapan Air}

Rasio tepung jewawut dan tepung beras tidak berpengaruh signifikan pada penguapan air kue kembang goyang seperti terlihat pada Gambar 6. Selama proses penggorengan, air dalam adonan menguap menjadi uap air. Sebelum proses penggorengan, adonan kue kembang goyang memiliki kadar air $39,93-54,81 \%$. Setelah proses penggorengan, kue kembang goyang memiliki kadar air yang relatif rendah, yaitu $2,25-4,78 \%$. Selama proses penggorengan dapat dinyatakan bahwa sekitar 90,57-94,76\% air menguap pada semua formula kue kembang goyang walaupun kadar air kue kembang goyang setelah digoreng tidak berbeda signifikan dengan kadar air kue kembang goyang sebelum digoreng. Hal ini diduga karena proses penggorengan yang dilakukan relatif singkat yaitu 30 detik. Waktu penggorengan pada setiap formulasi kue kembang goyang selama 30 detik belum menyebabkan perubahan persentase penguapan air yang signifikan. Hasil ini didukung oleh Manjunatha et al. (2014) yang melaporkan pada 15 detik awal penggorengan tidak terjadi penguapan air karena selama 15 detik awal proses penggorengan masih merupakan tahap inisiasi. Tahap inisiasi merupakan waktu yang dibutuhkan untuk meningkatkan panas dari suhu awal menuju ke titik didih air pada permukaan bahan pangan menggunakan minyak sebagai media perpindahan panas. Persentase penguapan air yang tidak berbeda signifikan pada semua formula kue kembang goyang diduga juga dipengaruhi oleh ketebalan adonan yang hampir sama dengan ketebalan cetakan kue kembang goyang yang digunakan. Hasil ini berbeda dengan penelitian sebelumnya yang melaporkan ketebalan adonan snack berpengaruh terhadap penurunan kadar air dan peningkatan kadar lemaknya. Semakin tipis adonan snack, maka semakin mudah air menguap dan semakin meningkat kadar lemaknya (Lumanlan et al., 2019).

Perbedaan konsentrasi santan pada semua formula juga tidak memberikan pengaruh signifikan terhadap persentase penguapan air kue kembang goyang seperti terlihat pada Gambar 7. Hal ini juga diduga terjadi karena kue kembang goyang digoreng hanya dalam waktu 30 detik sehingga perbedaan konsentrasi santan juga tidak memberikan pengaruh signifikan pada penguapan air selama tahap inisiasi. Perbedaan konsentrasi santan pada semua formula kue kembang goyang kemungkinan dapat memberikan pengaruh signifikan terhadap penguapan air pada waktu penggorengan yang lebih lama dari 30 detik. Hal ini didukung oleh penelitian sebelumnya yang melaporkan semakin lama waktu penggorengan maka penguapan air pada produk yang digoreng semakin meningkat (Manjunatha et al., 2014).

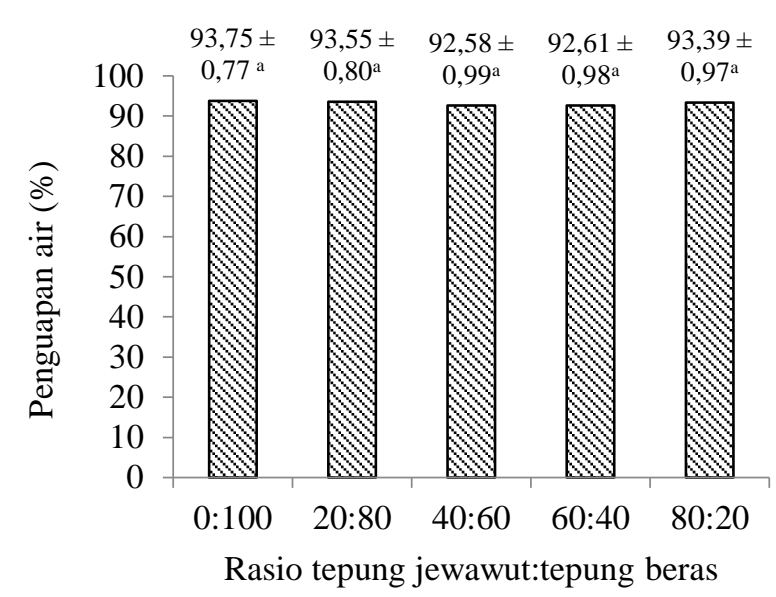

Gambar 6. Penguapan air kue kembang goyang pada rasio tepung jewawut dan tepung beras yang berbeda

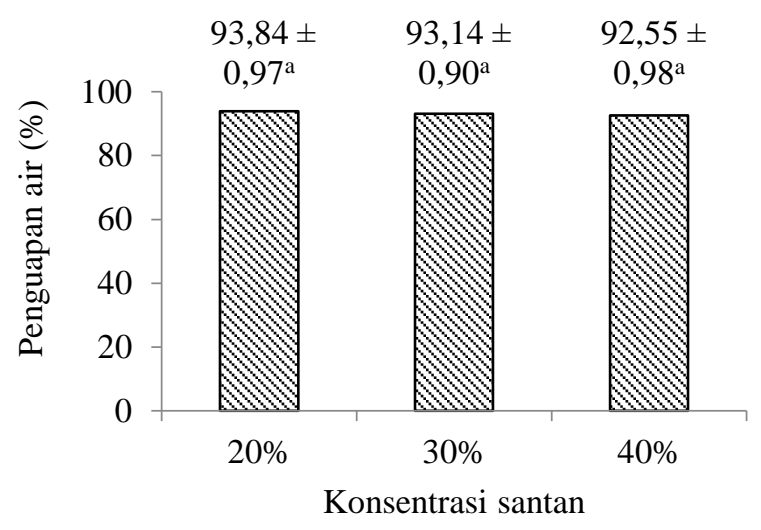

Gambar 7. Penguapan air kue kembang goyang pada konsentrasi santan yang berbeda

\section{Penentuan Formula Kue Kembang Goyang Terbaik dan Perbandingan dengan Kue Kembang Goyang Komersial}

Formula kue kembang goyang terbaik ditentukan berdasarkan hasil uji fisik kerenyahan (count peaks) dan absorpsi minyak. Formula kue kembang goyang terbaik terdapat pada rasio tepung jewawut:tepung beras 60:40 dan konsentrasi santan $30 \%$. Kue kembang goyang terbaik memiliki kerenyahan paling tinggi dibandingkan semua formula lainnya yang ditunjukkan dengan count peaks 266,00 \pm 0,99 dan absorpsi minyak yang menyerupai kontrol. Kerenyahan kue kembang goyang terbaik juga didukung dengan nilai toughness dan daya patah. 

Terakreditasi RISTEKDIKTI Peringkat SINTA 3, SK. 200/M/KPT/2020

Tabel 2. Perbandingan kue kembang goyang formula terbaik dengan kue kembang goyang komersial

\begin{tabular}{lcc}
\hline \multicolumn{1}{c}{ Parameter } & Kue Kembang Goyang Terbaik & Kue Kembang Goyang Komersial \\
\hline Count peaks & $266,00 \pm 0,99$ & $182,00 \pm 0,90$ \\
Toughness $(\mathrm{kgs})$ & $17,73 \pm 0,81$ & $32,82 \pm 0,89$ \\
Daya patah $(\mathrm{g})$ & $346,35 \pm 0,68$ & $508,00 \pm 0,63$ \\
Kadar pati resisten $(\%)$ & $1,58 \pm 0,02$ & $1,72 \pm 0,02$ \\
\hline
\end{tabular}

Perbandingan kue kembang goyang terbaik dengan kue kembang goyang komersial dapat dilihat pada Tabel 2. Kue kembang goyang terbaik memiliki count peaks yang lebih tinggi dan daya patah yang lebih rendah dibandingkan dengan kue kembang goyang komersial. Berdasarkan hasil tersebut, maka dapat dinyatakan kue kembang goyang terbaik dengan rasio tepung jewawut:tepung beras 60:40 dan konsentrasi santan 30\% memiliki tekstur yang lebih renyah dibandingkan dengan kue kembang goyang komersial. Tekstur yang lebih renyah pada kue kembang goyang terbaik diduga dipengaruhi oleh perbedaan kandungan lemak dalam santan. Keberadaan lemak menyelubungi protein dan granula pati sehingga menghalangi air untuk membentuk ikatan yang kuat dan kohesif dengan pati dan protein sehingga menghasilkan tekstur yang renyah atau lebih mudah patah (Mamat dan Hill, 2014).

Kadar pati resisten kue kembang goyang terbaik $(1,58 \pm 0,02 \%)$ (Tabel 2) lebih tinggi dibandingkan kadar pati resisten tepung jewawut $(0,83 \pm 0,03 \%)$ (Tabel 1). Kadar pati resisten kue kembang goyang lebih tinggi dibandingkan tepung jewawut diduga karena terbentuknya kompleks amilosa dengan lemak santan selama proses penggorengan. Pada Tabel 2 kadar pati resisten kue kembang goyang terbaik masih lebih rendah dibandingkan kadar pati resisten kue kembang goyang komersial $(1,72 \pm 0,02 \%)$. Perbedaan kadar pati resisten antara kue kembang goyang terbaik dengan kue kembang goyang komersial diduga berasal dari perbedaan komposisi pada formula kue kembang goyang khususnya tepung jewawut pada kue kembang goyang terbaik dan perbedaan kondisi penggorengan yang dilakukan. Substitusi tepung jewawut sampai 50\% pada produk kue kering tradisional Indonesia dapat diterima panelis walaupun belum dilaporkan secara spesifik kadar pati resistennya. Penelitian sebelumnya melaporkan substitusi tepung jewawut $30-50 \%$ pada kue kasippiq dapat diterima oleh panelis berdasarkan parameter penerimaan sensori keseluruhan (Hijrianti dan Widodo, 2018). Lebih lanjut, Widiyawati et al. (2020) melaporkan kadar serat pangan snack millet crispy sebesar 19,05 g/100 g produk yang dibuat dari $100 \%$ tepung jewawut. Kondisi penggorengan yang berbeda juga dapat memengaruhi perbedaan kadar pati resisten kue kembang goyang terbaik dan komersial. Proses penggorengan dengan metode deep frying dapat menurunkan kadar pati resisten karena hilangnya air sehingga mencegah kristalisasi rantai amilosa dan menyebabkan penurunan kadar pati resisten setelah penggorengan (Yadav dan Rajan, 2011).

\section{KESIMPULAN}

Kadar amilosa tepung jewawut berturut-turut untuk varietas erecta, compacta, glabra adalah $37,91 \pm 0,51 \% ; 24,41 \pm 0,78 \% ; 21,68 \pm 0,78 \%$. Kadar amilosa tertinggi terdapat pada tepung jewawut varietas erecta. Rasio tepung jewawut dan tepung beras berpengaruh terhadap tekstur dan absorpsi minyak kue kembang goyang. Semakin tinggi rasio tepung jewawut dalam formula maka menurunkan toughness, kerenyahan, dan absorpsi minyak, tetapi dapat meningkatkan daya patah kue kembang goyang. Konsentrasi santan yang semakin tinggi dalam formula dapat meningkatkan toughness, kerenyahan, daya patah, dan absorpsi minyak kue kembang goyang. Rasio tepung jewawut dan tepung beras 60:40 dan konsentrasi santan 30\% memberikan karakteristik tekstur kue kembang goyang terbaik yaitu kerenyahan (count peaks) $266 \pm 0,99$, toughness $17,73 \pm 0,81 \mathrm{kgs}$, daya patah $346,35 \pm 0,68 \mathrm{~g}$ dan absorpsi minyak yang menyerupai kontrol.

\section{DAFTAR PUSTAKA}

Andarwulan, N., F. Kusnandar, dan Herawati. 2011. Analisis Pangan. Jakarta: Dian Rakyat. 328 hal.

Andayani, R. 2013. Diversifikasi tepung cassava dalam pembuatan sagon, kembang goyang dan kecipir. Jurnal Khasanah Ilmu 4: 91-99. DOI:10.31294/khi.v4i1.467.

Annor, G.A., M. Marcone, E. Bertoft, and K. Seetharaman. 2014. Physical and molecular of millet starches. Cereal Chemistry 91: 286292. DOI:10.1094/CCHEM-08-13-0155-R. 
AOAC. 2012. Official Methods of Analysis of AOAC International. The Association Official Analytical Chemists. Rockville, MD. Methods 2002.02.

Chen, L., D.J. McClements, H. Zhang, Z. Zhang, Z. Jin, and Y. Tian. 2019. Impact of amylose content on structural changes and oil absorption of fried maize starches. Food Chemistry 287: 28-37. DOI:10.1016/ j.foodchem.2019.02.083.

Fernando, B. 2013. Rice as a source of fiber. Journal of Rice Research 1: 1-4. DOI:10.4172/jrr.1000e101.

Fuadah, I.E. dan C.A.N. Afifah. 2016. Pengaruh penambahan tepung bekatul terhadap mutu organoleptik kue kembang goyang. E-journal Boga 5: 18-26.

Gao, H., J. Cai, W. Han, H. Huai, Y. Chen, and C. Wei. 2014. Comparison of starches isolated from three different Trapa species. Food Hydrocolloids 37: 174-181. DOI:10.1016/ j.foodhyd.2013.11.001.

Harijono, W.H. Susanto, dan F. Ismet. 2012. Studi penggunaan proporsi tepung (sorgum ketan dengan beras ketan) dan tingkat kepekatan santan yang berbeda terhadap kualitas kue semprong. Jurnal Teknologi Pertanian 2: 111.

Hijrianti, S. dan S. Widodo. 2018. Substitusi tepung jewawut pada kue kassipiq di Desa Bonde Kecamatan Campalagian Kabupaten Polewali Mandar. Prosiding Seminar Nasional Sinergitas Multidisiplin Ilmu Pengetahuan dan Teknologi (SMIPT) 9-10 April 2018, Indonesia. pp. 294-300.

Himabindu, P. dan N. Devanna. 2017. Development of nutritious cookies by incorporating kodo and little millet flour. International Journal of Agriculture Science and Research 7: 681688.

Juhaeti, T., W. Widiyono, N. Setyowati, P. Lestari, F. Syarif, Saefuddin, I. Gunawan, Budiarjo, dan R.H. Agung. 2019. Serealia lokal jewawut (Setaria italica (L.) P. Beauv.: Gizi, budaya dan kuliner. Prosiding Seminar Nasional Biologi, Saintek, dan Pembelajarannya (SN-Biosper) 28 September 2019, Tasikmalaya, Indonesia. pp. 9-17.

Lumanlan, J.C., W.M.A.D.B. Fernando, and V. Jayasena. 2019. Mechanisms of oil uptake during deep frying and applications of predrying and hydrocolloids in reducing fat content of chips. International Journal of
Food Science and Technology. DOI:10.1111/ ijfs. 14435 .

Luna, P., H. Herawati, S. Widowati, dan A.B. Prianto. 2015. Pengaruh kandungan amilosa terhadap karakteristik fisik dan organoleptik nasi instan. Jurnal Penelitian Pascapanen Pertanian 12: 1-10. DOI:10.21082/jpasca. v12n1.2015.1-10.

Mamat, H. and E.S. Hill. 2014. Effect of fat types on the structural and textural properties of dough and semi-sweet biscuit. Journal of Food Science and Technology 51: 19982005. DOI:10.1007/s13197-012-0708-x.

Manjunatha, S.S., N. Ravi, P.S. Negi, P.S. Raju, and A.S. Bawa. 2014. Kinetics of moisture loss and oil uptake during deep fat frying of Gethi (Dioscorea kamoonensis Kunth) strips. Journal of Food Science and Technology 5: 3061-3071. DOI:10.1007/s13197-012-08416.

Mousa, R.M.A. 2016. Hydrocolloids of date pits used as edible coating to reduce oil uptake in potato strips during deep-fat frying. Journal of Food Science and Technology 13: 39-50.

Paula, A.M. and A.C. Conti-Silva. 2014. Texture profile and correlation between sensory and instrumental analyses on extruded snacks. Journal of Food Engineering 121: 9-14. DOI:10.1016/j.jfoodeng.2013.08.007.

Paz-Gamboa, E., E. Ramirez-Figueroa, M.A. VivarVera, H.R. Bravo-Delgado, O. CortesZavaleta, H. Ruiz-Espinosa, and I.I. RuizLopez. 2015. Study of oil uptake during deepfat frying of Taro (Colocasia esculenta) chips. CyTA Journal of Food 13: 506-511. DOI:10.1080/19476337.2015.1010587.

Raigond, P., R. Ezekiel, and B. Raigond. 2014. Resistant starch in food: A review. Journal of the Science of Food and Agriculture 95: 1968-1978. DOI:10.1002/ jsfa.6966.

Rathore, S., K. Singh, and V. Kumar. 2016. Millet grain processing, utilization and its role in health promotion: A review. International Journal of Nutrition and Food Sciences 5: 318-329. DOI:10.11648/j.ijnfs.20160505.12.

Sarita and E. Singh. 2016. Potential of millets: nutrients composition and health benefits. Journal of Scientific and Innovative Research 5: 46-50.

Widiyawati, E., N. Ratnaningsih, dan B. Lastariwati. 2020. Uji kesukaan dan kandungan gizi millet crispy dari tepung millet sebagai snack alternatif sumber serat. 
Warta Industri Hasil Pertanian 37:66-73. DOI:10.32765/wartaihp.v37i1.5907.

Yadav, D.N. and A. Rajan. 2011. Fibers as an additive for oil reduction in deep fat fried poori. Journal of Food Science and Technology 49: 767-773. DOI:10.1007/ s13197-010-0218-7.

This work is licensed under a Creative Commons Attribution-ShareAlike 4.0 International License. 